\title{
Características do sistema estomatognático de crianças respiradoras orais: enfoque antroposcópico $* * * * *$
}

\author{
Characteristics of the stomatognathic system of mouth breathing \\ children: anthroposcopic approach
}

\author{
Débora Martins Cattoni* \\ Fernanda Dreux Miranda Fernandes** \\ Renata Cantisani Di Francesco*** \\ Maria do Rosário Dias de Oliveira Latorre****
}

*Fonoaudióloga. Doutora em Ciências pela Faculdade de Medicina da Universidade de São Paulo. Endereço para correspondência: Rua Barão da Passagem, 1330 - Apto. 91C - São Paulo - SP - CEP 05087-000 (dmcattoni@uol.com.br)

**Fonoaudióloga. Livre-Docente. Professora Associada do Curso de Fonoaudiologia da Faculdade de Medicina da Universidade de São Paulo.

***Médica. Doutora em Medicina pela Faculdade de Medicina da Universidade de São Paulo. Médica Assistente Doutora da Divisão de Otorrinolaringologia do Hospital das Clínicas da Faculdade de Medicina da Universidade de São Paulo.

****Estatística. Professora Titular do Departamento de Epidemiologia da Faculdade de Saúde Pública da Universidade de São Paulo.

******Trabalho realizado na Faculdade de Medicina da Universidade de São Paulo

Artigo Original de Pesquisa Artigo Submetido a Avaliação por Pares Conflito de Interesse: não

Recebido em 13.06.2007. Revisado em 18.09.2007. Aceito para Publicação em 29.10.2007.

\begin{abstract}
Background: the use of anthroposcopy in the assessment of posture and morphology of the stomatognathic system of mouth breathing children. Aim: to describe the postural and morphologic characteristics of the stomatognathic system of mouth breathing children, according to age. Method: participants were 100 children, of both genders, with ages ranging from 7 to 11 years and 11 months, leukoderms, in mixed dentition and with the diagnosis of mouth breathing. The investigated postural and morphologic characteristics of the stomatognathic system were labial and lingual resting position, possibility of labial occlusion, hyperfunction of the mentalis muscle during labial occlusion, bite and morphology of the lower lip, cheeks and hard palate, using the anthroposcopy methodology. Results: the results referring to the characterization of the studied population, according to the most frequent otorhinolaryngologic diagnosis, was of enlarged pharyngeal and palatine tonsils. A statistically significant difference was found between the percentages of each otorhinolaryngologic diagnosis, according to age. The results of the characteristics of the stomatognathic system indicated that the most common aspects in the studied sample were: half-open lips when in the resting position, tongue lowered on the mouth's floor in the resting position, possibility of labial occlusion, hyperfunction of the mentalis muscle during labial occlusion, alterations of bite, labioverted, symmetry of the cheeks and alteration of the hard palate. All of the studied characteristics presented the same frequency with the increase in age, with no statistically significant difference. Conclusion: mouth breathing children presented pathologic adaptations in the postural and morphological characteristics of the stomatognathic system. This suggests the importance of early diagnosis in order to avoid orofacial alterations.

Key Words: Face; Stomatognathic System; Child; Mouth Breathing.
\end{abstract}

\section{Resumo}

Tema: a utilização da antroposcopia na avaliação das características posturais e morfológicas do sistema estomatognático de crianças respiradoras orais. Objetivo: descrever as características posturais e morfológicas do sistema estomatognático de crianças respiradoras orais, segundo a idade. Método: Participaram 100 crianças, de ambos os sexos, com idades entre 7 anos e 11 anos e 11 meses, leucodermas, em dentição mista e com diagnóstico de respiração oral. As características posturais e morfológicas do sistema estomatognático pesquisadas foram posição habitual de lábios e de língua, possibilidade de vedamento labial, hiperfunção do músculo mentual durante a oclusão labial, mordida e morfologia do lábio inferior, das bochechas e do palato duro, por meio da antroposcopia. Resultados: no que se refere à caracterização da população do estudo segundo o diagnóstico otorrinolaringológico principal, tem-se que foi mais freqüente o aumento de tonsila faríngea e de tonsilas palatinas. Não foi encontrada diferença estatisticamente significativa entre as porcentagens de cada diagnóstico otorrinolaringológico, de acordo com a idade. Os resultados relativos às características do sistema estomatognático indicaram que os aspectos mais comuns na amostra foram posição habitual de lábios entreaberta, posição habitual de língua no assoalho oral, possibilidade de vedamento labial, hiperfunção do músculo mentual durante a oclusão dos lábios, mordida alterada, lábio inferior com eversão, simetria de bochechas e palato duro alterado, sendo que todas as características estudadas apresentaram a mesma freqüência com o avançar da idade, não havendo diferença estatisticamente significativa de acordo com essa variável. Conclusão: as crianças respiradoras orais apresentaram adaptações patológicas das características posturais e morfológicas do sistema estomatognático, sugerindo a importância do diagnóstico precoce como forma de evitar alterações orofaciais.

Palavras-Chave: Face; Sistema Estomatognático; Criança; Respiração Bucal.

Referenciar este material como:

S (original title: Características do sistema estomatognático de crianças respiradoras orais: enfoque antroposcópico). Pró-Fono Revista de Atualização Científica. 2007 out-dez; 19(4):347-51. 


\section{Introduction}

In the evaluation of the orofacial myology, more specifically during the clinical exam, the focus is on the knowledge acquired from anthroposcopy (1-4).

The adaptations of the stomatognathic system in the mouth breathing individual frequently mentioned in the literature are: the tongue with dorsum elevation and tip depression, tongue lowered on the mouth's floor or protruded between the arches, thick and everted lower lip, mentalis muscle hyperfunction, flaccid lips, tongue and cheeks, tongue thrust, facial asymmetries, noisy breathing, an increase in height of face, narrow maxilla, malocclusion, open lips in resting position and ogival and narrow hard palate, among others (5-8).

The purpose of this study was to describe the postural and morphologic characteristics of the stomatognathic system of mouth breathing children, in reference to labial and lingual resting position, possibility of labial occlusion, mentalis muscle hyperfunction during labial occlusion, bite and morphology of lower lip, cheeks and hard palate, according to age.

\section{Method}

The research was approved by Ethics Committee (CAPPesq) of Hospital das Clínicas and Medical School of the University of Sao Paulo (protocol number 096/04). All the legal guardians of the children signed the informed consent form (ICF).

100 mouth breathing children were evaluated, with ages ranging from seven to 11 years and 11 months, with $51(51 \%)$ males and $49(49 \%)$ females. The mean age was 8 years and 5 months and the median was 8 years. The children were divided according to age:

.31 children (31\%) from 7 years to 7 years and 11 months;

. 22 children (22\%) from 8 years to 8 years and 11 months;

.21 children (21\%) from 9 years to 9 years and 11 months;

.12 children (12\%) from 10 years to 10 years and 11 months;

.14 children (14\%) from 11 years to 11 years and 11 months.

The inclusion criteria of the children in this study were:
. mouth breathing otolaryngologic diagnosis;

. functional alteration of breathing;

. leukoderm;

. mixed dentition period with four permanent first molars completely erupted.

The exclusion criteria of the children in this study were:

. history of speech-language pathology treatment (actual and/or previous);

. history of facial and/or pharyngeal surgery;

. history of syndrome and/or neurological disease and/or bifid uvula;

. history of orthodontics and/or facial orthopedics and/or craniomandibular treatments (actual and/ or previous) and/or temporomandibular joint dysfunction (TJD).

On the first phase, the otorhinolaryngologist realized the otolaryngologic evaluation, composed by physical and radiologic exams. If the child were diagnosed as mouth breather, it was verified if he/ she respected the others inclusion and exclusion criteria.

On the second phase, the speech-language pathology evaluation was done in order to investigate the functional alteration of the breathing, based on postural aspects of the lips and the tongue, as well on the morphologic aspects of the lower lip, cheeks, hard palate and bite, by anthroposcopic approach. The child was asked to sit down, with feet on the floor and with the head in the resting position. The researcher sat down in front of the child during the data collection.

In reference to the labial resting position, it was classified as:

1. Labial occlusion: when the lips were in adequate resting position, with contact.

2. Half-open lips: when the lips were apart, without contact between upper lip and lower lip.

3. Mouth-open: when lips were apart, with the mandible resting down, without contact between upper lip and lower lip.

During the speech-language pathology evaluation, the following aspects were also observed:

1. Possibility of labial occlusion: when the lips were half-open apart or open in the resting position, the child was asked to remain with closed lips during 30 seconds. If the child was able to, he/she was 
considered as having possibility of labial occlusion. The children who showed labial occlusion in the resting position were classified as having the possibility of labial occlusion.

2. Everted lower lip: it was verified if the lower lip was with eversion in the resting position, showing the vermilion or intraoral mucosa.

3. Mentalis muscle hyperfunction: it was observed if there was hyperfunction of mentalis muscle, characterized by the wrinkles in the mentual region, when the child was asked to remain with closed lips during 30 seconds.

In reference to the lingual resting position inside oral cavity, it was classified as:

1. Palatine papilla: when it was observed the contact of the anterior third of the tongue in palatine papilla region, on the hard palate.

2. Lowered on the mouth's floor: when it was observed that the tongue remained in mouth's floor. 3. Anterior resting position: when it was observed that the tongue remained in an anterior position, between incisors teeth.

4. Lateral resting position: when it was observed that the tongue remained in an lateral position, between posterior teeth.

5. Other position: when it was observed a different position.

6. Not observed: when it was not possible to verify the lingual resting position.

In reference to the cheeks, they were classified as symmetrical or asymmetrical, such as:

1. Symmetrical: when it was observed the same size, volume and height of the cheeks in both sides of the face.

2. Asymmetrical: when it was observed different size, volume and height of the cheeks between the right side and the left side of the face.

In reference to the bite, it was classified as normal or altered, such as:

1. Normal bite: when it was found harmony between the dental arches, in centric occlusion.
2. Altered bite: when it was found crowding, anterior open bite, unilateral or bilateral posterior open bite, anterior crossbite, unilateral or bilateral posterior crossbite, overbite, overjet or other bite alteration.

In reference to hard palate, it was classified as normal or altered:

1. Normal: when it was observed normal morphology of the hard palate according to height and width.

2. Altered: when it was found ogival and/or narrow hard palate.

\section{Statistical analysis}

The analysis of the association between age and the studied variables was made using chisquare association test. All analysis were processed with SPSS for Windows version 12.0 and the considered level of significance was $5 \%$.

\section{Results}

In reference to labial resting position, according to age, it was verified that the majority of children showed half-open lips $(67 \%)$ and $25 \%$ of the children showed labial occlusion. There was no significant statistical difference among the percentages of the labial resting positions, according to age $(\mathrm{p}=, 211)$.

In Table 1, it was observed that there was no significant statistical difference among the percentages of the lingual resting positions, according to age $(\mathrm{p}=0,792)$.

In Table 2, it was observed that there was no significant statistical difference among the percentages of the studied characteristics, according to age $(\mathrm{p}>0,05)$.

In Table 3, it was observed that there was statistical difference among the percentages of the bite, with increase of the frequency of the alteration beyond 8 years old $(p=0,051)$. It was not found significant statistical difference among the percentages in reference to the hard palate $(\mathrm{p}=$ $0,293)$, according to age. 
TABLE 1. Number and percentage of children in reference to lingual resting position, according to age

\begin{tabular}{|c|c|c|c|c|c|c|c|c|c|c|c|c|}
\hline \multirow[t]{4}{*}{ Age } & \multirow{4}{*}{$\mathrm{N}$ total } & \multirow{2}{*}{\multicolumn{2}{|c|}{$\begin{array}{l}\text { Palatine } \\
\text { papilla }\end{array}$}} & \multirow{2}{*}{\multicolumn{2}{|c|}{$\begin{array}{l}\text { Lowered on the } \\
\text { mouth's floor }\end{array}$}} & \multirow{2}{*}{\multicolumn{2}{|c|}{$\begin{array}{c}\text { Anterior resting } \\
\text { position }\end{array}$}} & \multirow{2}{*}{\multicolumn{2}{|c|}{$\begin{array}{c}\text { Lateral resting } \\
\text { position }\end{array}$}} & \multicolumn{2}{|c|}{ Not observed } & \multirow{4}{*}{$\mathrm{p}$} \\
\hline & & & & & & & & & & & \multirow{3}{*}{$\%$} & \\
\hline & & & & $\mathrm{N}$ & $\%$ & & & & & \multirow[t]{2}{*}{$\mathrm{N}$} & & \\
\hline & & $\mathrm{N}$ & $\%$ & & & $\mathrm{~N}$ & $\%$ & $\mathrm{~N}$ & $\%$ & & & \\
\hline 7 & 31 & 1 & 3,2 & 20 & 64,5 & 5 & 16,1 & 0 & ,0 & 7 & 22,6 & \\
\hline 8 & 22 & 0 & 0 & 17 & 77,3 & 0 & ,0 & 0 & , 0 & 8 & 36,4 & \\
\hline 9 & 21 & 0 & 0 & 14 & 66,7 & 2 & 9,5 & 0 & ,0 & 5 & 23,8 & 0,792 \\
\hline 10 & 12 & 1 & 8,3 & 5 & 41,7 & 1 & 8,3 & 0 & , 0 & 4 & 33,3 & \\
\hline 11 & 14 & 0 & 0 & 11 & 78,6 & 0 & 0 & 0 & 0 & 6 & 42,9 & \\
\hline TOTAL & 100 & 2 & 2,0 & 57 & 57,0 & 11 & 11,0 & 0 & 0 & 30 & 30,0 & \\
\hline
\end{tabular}

Legend: $\mathrm{N}=$ number; $\%=$ percentage

TABLE 2. Number and percentage of children with everted lower lip, possibility of labial occlusion, mentalis muscle hyperfunction and symmetry of cheeks, according to age

\begin{tabular}{|c|c|c|c|c|c|c|c|c|c|}
\hline \multirow[t]{3}{*}{ Age } & \multirow[t]{3}{*}{$\mathrm{N}$ total } & \multicolumn{2}{|c|}{ Everted lower lip } & \multirow{2}{*}{\multicolumn{2}{|c|}{$\begin{array}{c}\text { Possibility of labial } \\
\text { occlusion }\end{array}$}} & \multirow{2}{*}{\multicolumn{2}{|c|}{$\begin{array}{l}\text { Mentalis muscle } \\
\text { hyperfunction }\end{array}$}} & \multirow{2}{*}{\multicolumn{2}{|c|}{$\begin{array}{c}\text { Symmetry of } \\
\text { cheeks }\end{array}$}} \\
\hline & & \multirow[t]{2}{*}{$\mathrm{N}$} & \multirow[t]{2}{*}{$\%$} & & & & & & \\
\hline & & & & $\mathrm{N}$ & $\%$ & $\mathrm{~N}$ & $\%$ & $\mathrm{~N}$ & $\%$ \\
\hline 7 & 31 & 26 & 83,9 & 30 & 96,8 & 24 & 77,4 & 20 & 64,5 \\
\hline 8 & 22 & 17 & 77,3 & 22 & 100,0 & 15 & 68,2 & 20 & 90,9 \\
\hline 9 & 21 & 18 & 85,7 & 20 & 95,2 & 14 & 66,7 & 15 & 71,4 \\
\hline 10 & 12 & 11 & 91,7 & 12 & 100,0 & 4 & 33,3 & 8 & 66,7 \\
\hline 11 & 14 & 11 & 78,6 & 14 & 100,0 & 10 & 71,4 & 10 & 71,4 \\
\hline TOTAL & 100 & 83 & 83,0 & 98 & 98,0 & 67 & 67,0 & 73 & 73,0 \\
\hline & & & & & 729 & & & & \\
\hline
\end{tabular}

Legend: $\mathrm{N}=$ number; $\%=$ percentage 
TABLE 3. Number and percentage of children in reference to bite and hard palate, according to age

\begin{tabular}{|c|c|c|c|c|c|c|c|c|c|}
\hline \multirow[t]{3}{*}{ Age } & \multirow[t]{3}{*}{$\mathrm{N}$ total } & \multicolumn{4}{|c|}{ Bite } & \multicolumn{4}{|c|}{ Hard palate } \\
\hline & & \multicolumn{2}{|c|}{ normal } & \multicolumn{2}{|c|}{ altered } & \multicolumn{2}{|c|}{ normal } & \multicolumn{2}{|c|}{ altered } \\
\hline & & $\mathrm{N}$ & $\%$ & $\mathrm{~N}$ & $\%$ & $\mathrm{~N}$ & $\%$ & $\mathrm{~N}$ & $\%$ \\
\hline 7 & 31 & 8 & 25,8 & 23 & 74,2 & 14 & 45,2 & 17 & 54,8 \\
\hline 8 & 22 & 2 & 9,1 & 20 & 90,9 & 9 & 40,9 & 13 & 59,1 \\
\hline 9 & 21 & 2 & 9,5 & 19 & 90,5 & 5 & 23,8 & 16 & 76,2 \\
\hline 10 & 12 & 0 & , 0 & 12 & 100,0 & 2 & 16,7 & 10 & 83,3 \\
\hline 11 & 14 & 0 & ,0 & 14 & 100,0 & 6 & 42,9 & 8 & 57,1 \\
\hline \multirow[t]{2}{*}{ TOTAL } & 100 & 12 & 12,0 & 88 & 88,0 & 36 & 36,0 & 64 & 64,0 \\
\hline & $\mathrm{p}$ & \multicolumn{4}{|c|}{0,051} & \multicolumn{4}{|c|}{0,293} \\
\hline
\end{tabular}

Legend: $\mathrm{N}=$ number; $\%=$ percentage

\section{Discussion}

Only leukoderm children participated in this study, because differences in the orofacial morphology were shown in studies with different races (9-10).

It can also be observed everted lower lip in the mouth breathing individuals, due to the significant frequency of half-open lips in resting position and flaccid and hypofunction of orbicularis oris muscle. The data of this research confirm some studies $(5,7,8)$.

The possibility of labial occlusion was verified in the majority of the sample, what indicates that the mouth breathing children can remain the lips closed when asked, however it occurs with mentalis muscle hyperfunction, as a compensation of hypofunction of the lower lip in mouth breathers (7).

The hard palate and the bite were altered in the sample, what confirms some studies $(5,6,8,11,12)$. The bite was the only analyzed aspect with significant statistically difference, with increase of the frequency of the alteration beyond 8 years old. The others researched characteristics did not modify according to age and the alterations were found in equal percentages in all ages.

\section{Conclusion}

The studied postural and morphologic characteristics of the stomatognathic system in mouth breathing children showed the same frequency with increase of age. The most common studied aspects in the population sample were: halfopen lips in resting position, tongue lowered on the mouth's floor in resting position, mentalis muscle hyperfunction during labial occlusion, labioverted, symmetry of the cheeks, possibility of labial occlusion, altered bite and altered hard palate. 


\section{References}

1. Cattoni DM, Fernandes FDM, Marchesan IQ, Latorre MRDO. Medidas antropométricas faciais em crianças segundo períodos da dentição mista. Rev Cefac. 2003; 5(1):21-9.

2. Cattoni DM, Fernandes FDM. Medidas e proporções faciais em crianças: contribuições para a avaliação miofuncional orofacial. Pró-Fono. 2004;16(1):7-18.

3. Cattoni DM, Fernandes FDM, Andrade CRF, Latorre MRDO. Estudo sobre as medidas faciais em crianças: correlações com alteração de mordida e uso de aparelho ortodôntico. Rev Soc Bras Fonoaudiol. 2005;10(1):1-6.

4. Cattoni DM. O uso do paquímetro na avaliação da morfologia orofacial. Rev Soc Bras Fonoaudiol. 2006;11(1):52-8

5. Marchesan IQ. The speech pathology treatment with alterations of the stomatognathic system. Int $J$ Orofac Myol. 2000;26:5-12.

6. Junqueira PAS, Di Francesco RC, Trezza P, Zeratti FE, Frizzarini R, Faria MEJ. Alterações funcionais do sistema estomatognático pré e pós-adenoamigdalectomia. PróFono. 2002;14(1):17-22.
7. Andrade FV, Andrade DV, Araújo AS, Ribeiro ACC, Deccax LDG, Nemr K. Alterações estruturais de órgãos fonoarticulatórios e más oclusões dentárias em respiradores orais de 6 a 10 anos. Rev Cefac. 2005;7(3):318-25.

8. Rodrigues HOSN, Faria SR, Paula FSG, Motta AR. Ocorrência de respiração oral e alterações miofuncionais orofaciais em sujeitos em tratamento ortodôntico. Rev Cefac. 2005;7(3):356-62.

9. Le TT, Farkas LG, Ngim RCK, Levin S, Forrest CR. Proportionality in Asian and north American Caucasian faces using neoclassical facial canons as criteria. Aesth Plast Surg. 2002;26(1):64-9.

10. Porter JP. The average African American male face: na anthropometric analysis. Arch Facial Plast Surg. 2004;6:78-81.

11. Di Francesco RC. Respirador bucal: a visão do otorrinolaringologista. J Bras Fonoaudiol. 1999;1(1):5660.

12. Ribeiro F, Bianconi CC, Mesquita MCM, AssencioFerreira VJ. Respiração oral: alterações oclusais e hábitos orais. Rev Cefac. 2002;4(3):187-90. 